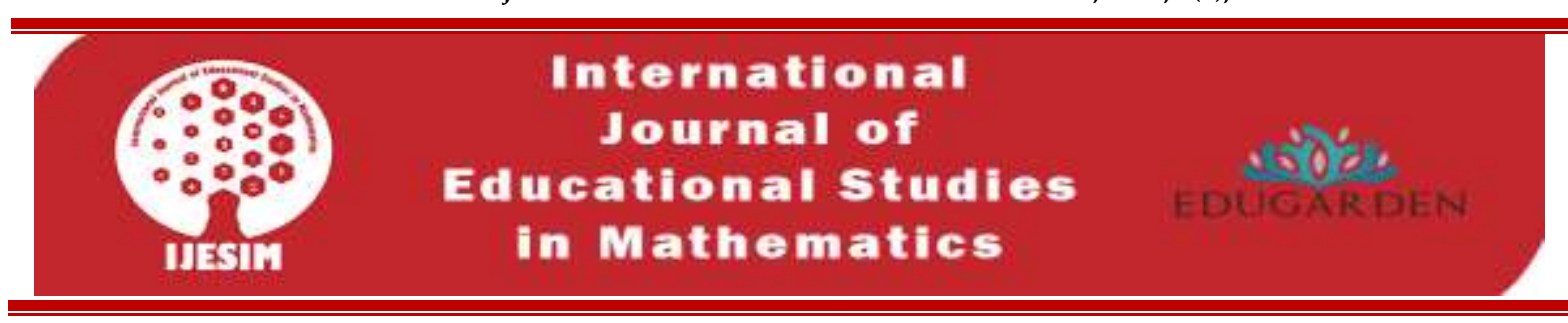

\title{
Project VLOGI (Video Lectures on Giving Instructions): Effects on Learners' Performance in Probability and Statistics
}

\section{Sherwin P. Batilantes}

Malay National High School, District of Malay, Schools Division Office - Aklan, Region VI - Western Visayas, Philippines

\begin{tabular}{|c|c|}
\hline ABSTRACT & ARTICLE INFO \\
\hline $\begin{array}{l}\text { This quantitative study ascertained the benefits of project VLOGI as an } \\
\text { intervention to the eighth-grade students in resolving the usual } \\
\text { unattained learning competencies in Probability and Statistics, especially } \\
\text { in the last quarter of the school year. The researcher utilized the true- } \\
\text { experimental research design using vlogs as an intervention to this study. } \\
\text { There were two (2) randomly selected classes out of the six (6) } \\
\text { heterogeneous classes in school as (1) the control group (prevailing } \\
\text { method) and (2) the experimental group (project VLOGI) in teaching. } \\
\text { Respondents underwent pre-test and post-test utilizing the quality } \\
\text { assured } 20 \text {-item multiple-choice type of questionnaires, reviewed and } \\
\text { verified by an expert panel of evaluators. The researcher used descriptive } \\
\text { and inferential analyses using the SPSS } 2.0 \text { tool to analyze and interpret } \\
\text { the outcomes. The study's significant results showed that learners } \\
\text { improved their academic performance in Probability and Statistics using } \\
\text { these vlogs. Likewise, learners gained knowledge while working on their } \\
\text { projects to create vlogs. Furthermore, by capturing learners' attention and } \\
\text { engaging them in their learning through various social media platforms, } \\
\text { project VLOGI was served as an alternative teaching method in any } \\
\text { discipline. Hence, project VLOGI was strongly recommended for teachers } \\
\text { as a replacement when they are out of class due to ancillary functions } \\
\text { in school to foster unattained learning competencies before the school } \\
\text { vear ends. }\end{array}$ & $\begin{array}{l}\text { Article History: } \\
\text { Received: } 03.10 .2021 \\
\text { Received in revised form: } 09.12 .2021 \\
\text { Accepted: } 13.12 .2021 \\
\text { Available online: } 14.12 .2021 \\
\text { Article Type: Standard paper } \\
\text { Keywords: vlogs, spiral progression } \\
\text { approach, ancillary functions, prerequisite } \\
\text { subjects, unattained learning competencies }\end{array}$ \\
\hline
\end{tabular}

\section{Introduction}

Most students see Mathematics as a difficult subject because of the adverse teaching style, difficulty following instructions, difficulty comprehending the topic, and difficulty memorizing its equations and problem-solving methods (Gafoor \& Kurukkan, 2015). Kunwar (2020) claimed that one of the underlying reasons for high school learners' anxiety in mathematics was their negative perception of the subject. Other learners who lack self-esteem and self-efficacy experienced mathematics anxiety because they were not adequately equipped to move to higher grade levels and tended to perform low in their subject mathematics (Rozgonjuk et al., 2020). However, if learners had previously mastered the prerequisite topics in their math courses using this spiral progression approach (SPA): then, their mathematics anxiety may have been reduced and overcome (Alegre et al., 2019). This allegation was

\footnotetext{
Corresponding author's address: Malay National High School, District of Malay, Schools Division Office - Aklan, Region VI - Western Visayas, Philippines e-mail: sherwin.batilantes001@deped.gov.ph DOI: https://doi.org/10.17278/ijesim.1004076

*This study was presented through virtual online presentation at the International Online Conference in Mathematics Education last May 26-29, 2021, Yildiz Technical University, Istanbul, Turkey.

${ }^{*}$ This study was also presented locally in the Philippines at Pulong-Kaalam: An Action Research Colloquium Series held via Zoom and Facebook Live on May 7, 2021 sponsored by Univeristy of the Philippines in the Visayas in collaboration with the DepEd Region VI - Western Visayas, Philippines. *BERF Funded Action Research in 2019 by DepEd Region VI - Western Visayas, Philippines.
} 
also supported by Ridhwaanah and Khemduth (2019), that the spiral progression approach in teaching has positive impacts on learners in terms of mathematical fluency, content retention, and mastery of the concepts. In addition, the significant motivator in spiral education is that; the learning concepts presented in early lessons are frequently discussed as they progress in yearly grade levels, which may also significantly improve student comprehension (Ridhwaanah \& Khemduth, 2019).

Nevertheless, this spiral progression approach to teaching is not limited to mathematics education; however, other teachers teaching in any discipline may still use this approach (Yumusak, 2016), and it was prevalent in countries with this implemented adaptation of the $\mathrm{K}-12$ curriculum (Paring et al., 2021). Consequently, to avoid the mathematics anxiety of learners (Khoule et al., 2017), teachers must attain the required competencies in the curriculum before the school year ends since the fundamental prerequisite subjects are critical when learners advance to higher grade levels (Deken et al., 2019). Conversely, it was not true for all courses; though, it did occur in mathematical content, especially in Probability and Statistics. It would result in a domino effect in successive years (Zamalia \& Porter, 2016).

Probability and Statistics is one of the contents in the mathematics curriculum in grades 7 to 10 (Capate \& Lapinid, 2015). In fact, according to the Trends in International Mathematics and Science Study (TIMSS) and Progress in International Reading Literacy Study (PIRLS) that countries just like the United States of America, Canada, Australia, Malaysia, Indonesia, New Zealand, Turkey, Spain, Philippines, among others, have this mathematical content of Probability and Statistics in the last quarter of their curriculum in Mathematics 8 or lower secondary grades (Mullis et al., 2016).

In the present situation, because of the pandemic, the importance of Probability and Statistics has been highlighted when experts utilized these concepts, such as interpreting and analyzing data, in assisting the government in every nation worldwide in flattening the curve of COVID 19 virus-infected people all over the world (Overton et al., 2020). Furthermore, Tiro (2020) asserts that a statistically literate individual can recognize the probable outcomes based on the essential data provided to the public through this content, Probability and Statistics. Moreover, Aizikovitsh-Udi (2019) said that it was clear that learners may build critical thinking skills via probability models, enhance intuitive judgment, and provide thoughtful decision-making under uncertainty, even utilizing only the statistical data provided to them.

However, Muniz-Rodriguez et al. (2020) performed recent research on the lack of statistical and probabilistic literacy among people, which is impacting the global catastrophe caused by the COVID19 pandemic. This study emphasized that lack of mathematical understanding about Probability and Statistics influenced the COVID 19 coronavirus curve's drastic increase, increasing mortality rate. Also, the study concluded that the deficit of comprehension on statistical data among citizens, particularly in high school learners, was correlated to secondary mathematics teachers. That was why the recent study strongly suggested that secondary mathematics teachers should improve their pedagogy to enhance learners' statistical and probabilistic literacy to answer the demands of today's data society (MunizRodriguez et al., 2020). Furthermore, Abad and Arellano (2020) discovered that learners' level of achievement in Probability and Statistics was deficient; learners considered Probability and Statistics a complicated area of mathematics since the concepts related to this area were new to them caused them confusion.

Similarly, the researcher linked this gap in his classroom setting in response to the latter assertion of the recently completed studies mentioned above. Since this mathematical content of Probability and Statistics was presented in the last quarter of the school year, the researcher discovered a low level of proficiency in higher grades due to SPA in teaching not being met, affecting learners' performances comprehending the subject. This allegation was supported by (Lopes, 2008 as cited in da Silva et al., 2020, pp. 3-5), who said that mathematics teachers often neglected the subject, Probability, and Statistics, for various reasons similar to ancillary functions in school. Furthermore, due to time constraints comparable to teacher's ancillary functions, some mathematics teachers who previously taught in the lower grades tend to have unattained learning competencies in the last quarter of the school year (Into 
\& Gempes, 2018). As a result, learners could not master the required competency since the prerequisite concepts in the lower grade level were not fulfilled, causing learners to experience mathematics anxiety in higher grades (Ernawati \& Sutiarso, 2020). Consequently, the spiral progression approach in teaching, which is supposed to have in education, shifted into a broken spiral in the curriculum (Orale \& Uy, 2018).

In the Philippines, despite all of the factors influencing teachers' performance in their duties similar to teachers' ancillary functions in school, teachers are nevertheless obliged to conduct make-up lessons for the missed school days (DepEd Order No. 009, 2005; DepEd Order 109, 2009). These DepEd Orders of the Philippines encourage classroom teachers to reschedule missed school days outside of the school calendar, especially on Saturdays, during mid-year break, or throughout the remaining months of the school year. As a result, the school, especially the subject teachers, may implement any modularized teaching to enable students to finish studies at home to compensate for the loss of class hours. Furthermore, the development of any form of instructional materials is a tool for the effective academic performance of learners (DepEd Order No. 35, s. 1998). It was supported by the DepEd Learning Action Cell (LAC) that exploring interventions to address the identified need could be in the form of learning materials, instructional materials, equipment, facilities, teaching strategies, teaching modalities, and so on (DepEd Order No. 35, s. 2016). These were the motivations behind the researcher's desire to create this intervention, named project VLOGI, to bridge the gap in the existing issues circulating in the content of Probability and Statistics. The researcher was interested in solving this problem using Information and Communication Technology (ICT) to cater to the generation Z (born 2001 to 2020) learners by attending lectures through vlogging.

Conversely, the teacher plays a vital role in establishing an exciting learning atmosphere where their students may thrive academically (Rashid \& Zaman, 2018). That is why teachers must continuously improve their teaching techniques by researching online media and contemporary informatory tools to instill creativity in their classrooms with the use of technology (Kırıkçlar \& Yıldız, 2019). Consequently, to respond to the statements mentioned above by the authors and the orders provided by the Department of Education (DepEd) in the Philippines, the researcher had conducted this classroom action research (Kunasaraphan, 2018) to his instructions, and project VLOGI was his intervention. This assertion was supported by (Fitriani \& Rohman, 2021), who claimed that instructional vlogs created and posted to YouTube through a project-based learning model were effective and feasible learning modalities in distance education, increasing mathematical communication skills.

The researcher's intervention, named project VLOGI, was inspired by video blogging (Vlog), the new blogging trend for digital natives in contemporary times (Gao et al., 2010). At present, Vlog has a lot to offer in an educational setting, like in the current situations because of the COVID-19 pandemic; Vlogs may consider as Support Instructional Materials (SIM) in blended learning modalities for instruction (Huang, 2021). Likewise, the argument was also supported by Batubara and Natali (2020) that in this contemporary age of technology, learners may utilize Vlogs to create a positive environment, enhance their skills, and motivate their interest in the lesson. One of them is media design, which requires students to be active and creative to generate and develop innovative ideas. Furthermore, this video blogging has a richer web experience than conventional text blogging because it integrates movies, sound, video prompt images, and text, increasing the information - and potential emotions - shared with users (Rahkmanina \& Kusumaningrum, 2017).

Similarly, according to Lalian (2019), using videos as a learning medium in mathematics improves students' motivation to learn, comprehension and interpretation of the lesson, and achievement. Nevertheless, despite the advantages that technology has provided to individuals in the contemporary world, traditional education has been replaced by a New Normal education resulting from the pandemic. There are still disadvantages that video-based learning has brought to learners, including the need for technological equipment, internet connectivity, extended contact time with the devices, and loss of focus due to internet exposure (Beheshti et al., 2018). However, distance learning through modular instruction platforms was also employed in some countries, just like the Philippines. This 
modular learning platform is designed to cater to learners in remote locations where technology and internet connection are unavailable for online learning; where they can manage their time at their own pace to focus on their weekly assigned performance tasks (Dangle \& Sumaoang, 2020).

Nonetheless, whatever situations and hindrances to learning that learners may encounter, the government and the department of education have always had solutions to have sustainability in education with the help of the teachers. As a result, the researcher's options in mind was this project VLOGI which would be attractive to learners since it is currently the trend among digital natives through these vlogs (Fitriani \& Rohman, 2021). Similarly, due to the pandemic, it is also very timely and relevant to be utilized as (SIM) as Vlogs in the asynchronous or synchronous platform of teaching (Rigo \& Mikus, 2021). These created vlogs were a combination of the researcher's and the submitted learners' project vlogs in their Mathematics subject, compiled as project VLOGI (Video Lectures on Giving Instruction). The study's intervention was associated with the Cognitive Theory of Multimedia Learning (Mayer, 2014), which explains the processes in learners' brains during meaningful learning were through multimedia teaching. This multimedia in education describes using words and images (verbal and visual) and at the same time in kinesthetic since they are also learning while working with their vlogs to enable multimedia learning effectively to learners. This theory has apparent implications for instructional design to assist multimedia learning, mainly preventing cognitive overload to learners. Furthermore, in this theory, learning is an active process of filtering, choosing, organizing, and integrating information based on learners' previous knowledge.

This quantitative research study aimed to test the effectiveness of project VLOGI as an intervention to enhance the eight-grade students' academic performances in the mathematical content of Probability and Statistics. Furthermore, using a true-experimental research design assisted the researcher and the teachers achieve the Department of Education curriculum guide's required learning competencies even without interfering with their duties as classroom teachers and obligations as teachers accompanied by ancillary functions. Therefore, this experimental research study explicitly sought to answer the following questions: (1) What is the students' performance in the pre-test of Probability and Statistics for those exposed in the prevailing method and project VLOGI? (2) Is there a significant difference in students' performance in the pre-test of Probability and Statistics between those exposed in the prevailing and project VLOGI? (3) What is the students' performance in the post-test of Probability and Statistics for those exposed in the conventional method and project VLOGI? (4) Is there a significant difference in students' performance in the post-test of Probability and Statistics between those exposed in the prevailing and project VLOGI?

\section{Method}

This study used a true-experimental research design (Ariel et al., 2021) since the two groups were chosen at random and designated as follows: (1) experimental group, using the project VLOGI intervention in teaching, and (2) control group, using the prevailing method of teaching. Figure 1 illustrates the trueexperimental study's conceptual framework, in which both groups underwent a pre-test and a post-test before and after the interventions (Kilicaslan \& Vural, 2018).

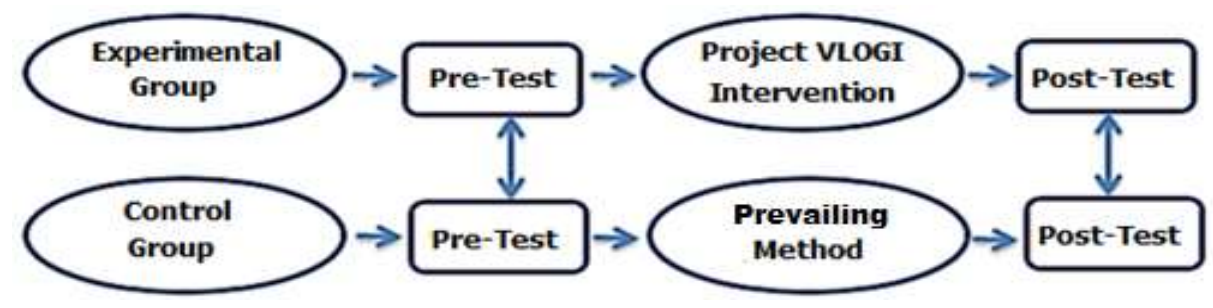

Figure 1. The conceptual framework of the true-experimental research design.

The study employed descriptive and inferential analyses (Chanoknath \& Louangrath, 2015) to assess project VLOGI as an alternative teaching method in enhancing learners' academic performance in 
mathematics learning competencies, particularly in the last quarter of Mathematics 8 content in Probability and Statistics.

\subsection{Participants and Other Source of Data}

The study's respondents were eight-grade students from Malay National High School, Motag, Malay, Aklan, Philippines, with two groups of classes utilizing the cluster sampling technique in simple random method from a total of six (6) heterogeneous classes of Grade 8 in the same school. There were 50 students in Grade 8 section Topaz and 50 students in Grade 8 section Jade, yielding 100 students total population as the research participants. The researcher used the true-experimental research design and the simple random sampling technique to choose which group of students would be the Control group (prevailing method) and Experimental group (Project VLOGI). The five (5) weeks duration sustained the entire study as stipulated in the learning competency codes in Math 8 content of Probability and Statistics (K to 12 Mathematics Curriculum Guide, 2016) to guide teachers on how many days or hours are allocated in each learning competency. These were the learning competencies that fall in the last quarter of the curriculum guide before the school year ends. Teachers often neglected these learning competencies and became the least learned competencies due to time constraints related to some factors affecting teacher's performance in school (da Silva et al., 2020).

\subsection{Data Gathering Methods}

The quality-assured and ready-made questionnaires evaluated and validated by an expert panel of evaluators in the DepEd central office served as the research instrument adapted from the DepEd Mathematics - 8 Learner's Module (2013). The eighth-grade learners across the Philippines widely use this Learner's Module in Mathematics 8. These questionnaires were used as a pre-test and a post-test, respectively, before and after the intervention. The questionnaire was a 20-item multiple-choice test, with each question linked to a specific learning competency in the mathematical content of Probability and Statistics. However, to ensure the validity and reliability of the ready-made questionnaires, another expert panel of evaluators was invited to examine the test items' content and consistency. Within one (1) hour, the two groups, (1) the control group utilizing the prevailing method and (2) the experimental group employing project VLOGI in teaching, were exposed to the same type of 20-item multiple-choice test. By comparing the pre-test and the post-test scores of all respondents, data was gathered and compiled for statistical analysis.

The study was a quantitative type of research (Jaron et al., 2015) measuring the numbers taken from the recorded observations and collected data. In this study, the researcher employed a $5 \%$ standard of meaning to determine whether to accept or reject the null hypothesis. The researcher used descriptive statistics using the mean and standard deviation to evaluate data by describing the relationship between variables in two (2) independent sample populations (Kaur et al., 2018). Furthermore, the independentsample t-test that compares the means of two separate or unrelated groups was used for the inferential statistics to determine if two independent groups differed substantially from one another (Hae-Young, 2019). This independent-sample t-test was utilized since the study was involved two unrelated variables; the control group and the experimental group. Then, using a probability sampling method, samples were drawn. Moreover, the Cohen's $d$ was utilized to determine the effect size in determining how significantly different the two independent groups were in terms of their magnitude (Fritz et al., 2011). Hence, the researcher used the Statistical Package for Social Science (SPSS) tool to manipulate, analyze, and present the data to generate significant differences between two independent sample groups (Landau \& Everitt, 2004).

\subsection{Intervention}

The intervention, dubbed project VLOGI, was primarily inspired by vlogging. Vlogging has been so common worldwide that some people make a living out of it (Gao et al., 2010). That is why some of the learners were influenced and aspired to become YouTubers someday. However, the researcher had found that Vlogs can be a great help in teaching since they were incredibly influential, interactive, and 
engaging to learners when they had their school's project of making vlogs in line with their lessons. Likewise, in making Vlogs, learners were learning while doing and fostering collaborative learning with their peers at the same time. This allegation was supported by Fidan and Debbag (2018), that Vlogs were a flexible and innovative way of teaching where learners enhanced their reflective learning and communication through social learning with their peers.

Furthermore, the researcher had also found that through Vlogs, learners could develop their 21st learning skills such as; innovation, creativity, teamwork, collaboration, ICT literacy, public speaking and presenting, critical thinking, problem-solving, artistry, self-expression, planning, and so on. These created Vlogs were a compilation from the researcher's Vlogs and the learners' project Vlogs as an intervention called project VLOGI (Video Lectures on Giving Instructions). This intervention project VLOGI was created to fill the observed gaps in the mathematical content and evaluate the impact of their participation and acceptance on this intervention. But, it may also assist teachers in developing more dynamic and interactive support instructional resources for learners to enhance and engage teaching and learning processes. Figure 2 shows the examples of this project VLOGI used for instruction.

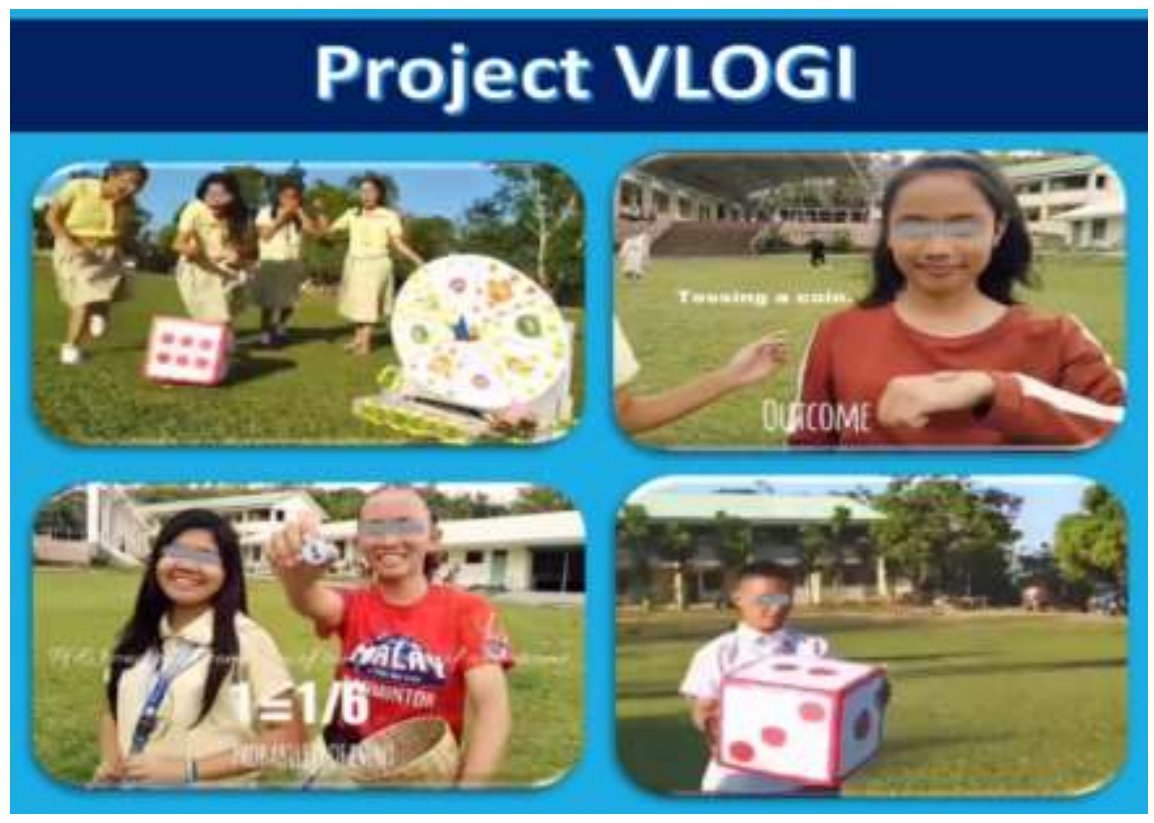

Figure 2. Project VLOGI samples used for Mathematics Instruction.

\subsection{Intervention's Procedure}

The processes used by the instructor in his classroom to arrange instructions and carry out the curriculum are referred to as teaching methods. These are methods and procedures that are based on educational theories and are used to predict behaviors under certain pedagogical circumstances (Abah, 2020). Teachers in today's classrooms, according to Ullah and Iqbal (2020), use two types of teaching methods: (1) the prevailing (conventional/traditional) method of teaching, which is the prevailing lecture type of teaching that focuses on memorization and recitation, and (2) the modern teaching methodology that focuses on interactive activities. This interactive teaching approach is currently linked with educational technology (Tuma, 2021), which is widely utilized as a modern-day intervention via distant, online, and blended learning (Rosenbusch, 2020). These are suitable teaching platforms in current COVID-19 pandemic-related health crises (Al-Maroof et al., 2020).

The researcher used the Prevailing Method of instruction socially (face-to-face) using the chalk and chalkboard, paper and pen, manila paper, recitation, memorization, drills or quizzes, seatwork, group activities, and so on. Furthermore, the researcher used a textbook supplied by the Philippine Department of Education as the primary source of instruction to assist teaching and learning in the mathematics curriculum. Since textbooks are limited in the Philippines' public high schools (Read \& 
Atinc, 2017; Hernando-Malipot, 2019), students just read and copied what was on the textbook while the instructor was absent due to unforeseen situations at school. As a result, the latter statement was heard several times during the experimentation because the researcher was assigned to several school functions. The researcher's school functions were mathematics coordinator, ICT coordinator, LIS (Learners Information System), EBEIS (Enhanced Basic Education Information System) coordinator, and a classroom subject teacher. Thus, this control group was given seatwork or tasks at home without a teacher's aid or any intervention. Furthermore, when the instructor returns to school, this group will continue to attend lessons to complete their given responsibilities, such as homework, group projects, group work activities, and so on.

On the other hand, the experimental group utilized Project VLOGI, a collection of video vlogs produced by the researcher and eighth-grade students. This technique was often used in distant education (Sumuglu, 2021), when the teacher and students are physically separated during class discussions in continuing education (Cassiba et al., 2021). This project VLOGI, on the other hand, maybe seen offline at school, even if the teacher is absent owing to ancillary functions. The main difference was that learners might have less time to review the project VLOGI within the classroom than when they review them at home. As a result, in this research, while the teacher is at school doing ancillary duties and is unable to attend his class, this project VLOGI is utilized as an educational support approach for the whole class period. Students often watched these videos in their classrooms through multimedia presentations or the e-classroom (computer room) to prevent missing lectures.

Furthermore, when the teacher is absent for an extended period of time due to training or seminars attended, as well as other unexpected situations, the project VLOGI is uploaded to any social media platform to be accessed online. The uploaded VLOGI project is accompanied by lectures and exercises that must be completed before returning to school. Teachers may then ensure that students have not missed any competencies in the curriculum and can continue with the lessons. Moreover, suppose the students cannot access or see the uploaded project VLOGI online due to limited technology access in their homes. In that case, they may watch the videos in school with the assistance of the school ICT teacher assigned to the e-classroom, and they were then given sufficient time to complete their performance tasks for consideration.

The filming process of project VLOGI was composed of three stages: The first stage was called the Planning (Pre-production) Stage - it involves gathering the necessary equipment, such as a video camera, a sound recorder, and improvise reflectors, as well as the script for the talents (students) and the tools to be used, such as improvised dice, roulette, and so on. The ideal day and time were selected based on the weather forecast, and the shooting location was also considered at this stage. The second stage was the Filming (Production) Stage, which requires rigorous preparation of talents for filming, coordination of the team (group of students), and ensuring that everyone in the immediate vicinity was aware of the filming process to prevent interferences. The last stage was known as the Output (Post-production) Stage. In this stage, an experienced team of assessors evaluated the films based on the material's validity and reliability connected to the mathematics eight learning competencies. Editing tools such as Filmora for video editing and Audacity for sound editing were also utilized throughout the production. Finally, the Vlogs are edited and saved offline and online for sustainable educational resources for learners and teachers. Throughout the study, the researcher utilized project VLOGI as an intervention in the experimental group compared to the control group, which used a prevailing teaching method. During experimentation, these Vlogs were used in the classroom, audio-visual room, or e-classroom even without the teacher's supervision, and only this project VLOGI intervention was provided for instruction.

\subsection{Ethical Issue}

The respondents' involvement was critical to the study's success. Strict attention to ethical norms is needed to prevent conflicts with research participants during the duration of this study. The researcher requested permission from the principal to perform his school's experimental research study by sending 
an official letter outlining the purpose, benefits, schedule, plan, and target respondents involved. Similarly, parental consent was sought in order to verify that their children had been selected to participate in the study. The final aim of the study began when parents consented to the researcher's conditions by signing the parental permission form. These specific criteria include presenting the study findings in public and publishing the research results in any respectable national or international journal publication. The orientations, directions, and progression of the study are all anxiously anticipated the whole time. The data and results received from respondents were completely private and were solely utilized for research purposes.

\section{Results and Discussions}

The researcher used an experimental research design in this study with two independent samples: (1) the control group used the prevailing teaching method, and (2) the experimental group used the project VLOGI intervention in teaching. The eight-grade students' academic performance in Probability and Statistics was assessed before and after the intervention using a pre-test and post-test with the same set of administered questionnaires to both groups. Similarly, the significant differences were analyzed (1) before the intervention to see the homogeneity of both groups, (2) to see if the intervention project VLOGI was an efficient approach compared to the prevailing teaching method. These were made possible by using the SPSS tool to evaluate the descriptive and inferential statistics of the study. Hence, the study's significant findings helped the researcher determine what actions should be taken to ensure that this project VLOGI will be accepted and implemented in teaching practice.

\subsection{Pre-test Results of Prevailing and Project VLOGI Groups in Probability and Statistics}

As indicated in Table 1, the eight-grade students' pre-test performance in the control group or prevaling method $(M=5.26, S D=2.05)$ and experimental group or project VLOGI $(M=5.08, S D=1.77)$ out of the 20item multiple-choice type of test and the results were deemed "Unacceptable" with the description shown below the Table 1. These results revealed that both groups of learners were performing at about the same level of comprehension prior to the intervention. As a result, despite having no previous awareness of the experimentation process topics (Hailikari et al., 2008), their comprehension standards were comparable (Paul \& Jefferson, 2019) for the fourth quarter learning competencies in the eighthgrade Mathematics. About the fact that they were chosen at random per segment or class as respondents, the findings revealed that they came from a homogeneous community of learners with the same level of mathematics eight performance. As a result of the homogeneity of the research participants (Chatterjee \& Mukherjee, 2016), it is worthwhile for the researcher to begin his study.

Furthermore, as shown in Table 1, an independent-samples t-test was conducted to compare students' performance in the pre-test exposed in the control group (prevailing method) and experimental group (project VLOGI) before the intervention. The analysis indicated that there was no significant difference in the pre-test scores of learners exposed in the prevailing method $(M=5.26, S D=2.05)$ and project VLOGI $(M=5.08, S D=1.77) ; t(98)=0.47, p=0.64$. This result illustrates a comparable level of thinking to both groups in Probability and Statistics before the conducted intervention. Likewise, the outcome explains an equivalent level of thinking in both groups in the eight-grade mathematics fourth-quarter learning competencies before the intervention.

Table 1. The significant difference in the pre-test exposed for the prevailing method and project VLOGI.

\begin{tabular}{lcccccc}
\hline Group & $\mathrm{N}$ & Mean & SD & Df & t-value & p-value \\
\hline Control Group & 50 & 5.26 & 2.05 & 98 & 0.47 & 0.64 \\
Experimental Group & 50 & 5.08 & 1.77 & & & \\
\hline
\end{tabular}

$p>0.05$. Note: Description that corresponds with the following scale (20-item multiple-choice test). $15.00-$ 20.00 (Highly Acceptable), 8.00 -14.00 (Acceptable), 1.00 - 7.00 (Unacceptable). 


\subsection{Post-test Results of Prevailing and Project VLOGI Groups in Probability and Statistics}

As described in Table 2, the eight-grade students in the control group or prevailing method $(M=8.20$, $S D=2.00)$ and experimental group or project VLOGI $(M=9.54, S D=2.10)$ out of the 20-item multiplechoice type of test. Both groups of respondents performed "Acceptable" based on the descriptions below in Table 3 after the intervention. These results displayed satisfactory performance of both groups in Probability and Statistics after the conducted intervention. Similarly, the learners' performance in the post-test was determined "Acceptable," since the mean scores for both groups exceeded half of the passing criterion, as shown below the Table 2 . While the results showed that neither group's mean scores met the 75 percent required for mastery of all learning competencies (Buensuceso, 2015) in the fourth quarter, they (research participants) showed a substantial improvement in post-test scores in comparison to the pre-test levels (Shivaraju et al., 2017).

Moreover, as shown in Table 2, the researcher used the independent sample t-test to compare the student's performance in the post-test exposed in the control group (prevailing method) and the experimental group (project VLOGI), after the intervention. The findings showed a significant difference in post-test scores between students subjected to the Prevailing Method $(M=8.20, S D=2.00)$ and Project VLOGI $(M=9.54, S D=2.10) ; t(98)=-3.27, p=0.002$. The findings revealed that the intervention project VLOGI mean scores were higher than the Prevailing Method mean scores. Since the results demonstrated a statistical significance of the two independent samples, the Cohen's $d$ was calculated to be 0.65 , indicating that both groups have a medium effect size. The findings revealed that the intervention project VLOGI was a more successful way to educate learners than the prevailing teaching method with no intervention.

Consequently, any intervention in a classroom setting, particularly in addressing learning gaps among learners, has a beneficial impact on the teaching and learning process (Machera, 2017). Furthermore, multimedia instructions, such as Vlogs for educational purposes, assisted learners in improving their academic performance in any discipline and increasing their motivation to learn (Bravo et al., 2011). Moreover, this project VLOGI or Vlogs for instruction, may be used as an alternate method in teaching if teachers are absent from class discussions because of ancillary school functions. Thus, the teachers could perform their duties efficiently without affecting their responsibilities as classroom teachers and school workers due to ancillary functions designated to them (Into \& Gempes, 2018).

Table 2. The significant difference in the post-test exposed for the prevailing method and project VLOGI.

\begin{tabular}{|c|c|c|c|c|c|c|}
\hline Group & $\mathrm{N}$ & Mean & SD & Df & t-value & $\mathrm{p}$-value \\
\hline Control Group & 50 & 8.20 & 2.00 & 98 & -3.27 & $0.002^{* *}$ \\
\hline Experimental Group & 50 & 9.54 & 2.10 & & & \\
\hline
\end{tabular}

\section{Conclusion and Discussion}

The following are the study's significant findings. First, prior to the intervention, learners' performance levels in the pre-test exposed to various interventions were inadequate. Because the mean scores do not exceed half of the scores given in the description, the verbal interpretation noticed in their pre-test scores was "Not Acceptable." Second, their performance levels were comparable, with no discernible difference in pre-test evaluations between the two groups receiving different interventions. The findings showed that their mathematics content performance levels in eight-grade were equivalent.

Similarly, neither group had any prior knowledge of the grade eight mathematics subjects in the fourthquarter academic competence. In addition, the researcher accepted the null hypothesis and was able to conduct the study since the homogeneity of the research participants was observed, even though they were selected at random. Third, the post-test improved the learner's performance level in both groups exposed to prevailing methods and project VLOGI. When compared to their pre-test scores, their posttest scores rose significantly. Consequently, the researcher determined "Acceptable" for the mean scores 
of both groups after the experimentation since their scores exceeded half of the test scores specified in the criteria. Finally, there was a large discrepancy in post-test results between the two treatment groups. It was discovered that project VLOGI was a more effective intervention than the prevailing teaching method with no introduced intervention. Similarly, when the researcher estimated the impact size between two groups using the Cohen's $d$ (Fritz et al., 2012), the findings revealed a medium effect size; however, the magnitude for their mean scores differed. Thus, it is conclusive to claim that project VLOGI can improve learners' academic performance in the mathematical content of Probability and Statistics even when the teacher is not present for discussion. Similarly, project VLOGI may assist learners in dealing with their mathematics anxiety since they will be less anxious than in a typical classroom setting.

The project VLOGI was an intervention utilizing academic Vlogs for teaching associated with the learning competencies in Mathematics 8 content in Probability and Statistics. These Vlogs combined with the learner project vlogs as part of their mathematics subject requirements and the researcher's vlogs. This project VLOGI was designed not only to help learners improve their academic performance in the mathematical content of Probability and Statistics, but it was also intended for teachers to promote the spiral SPA in teaching Mathematics. Through this SPA in teaching math or any discipline, learners could have a basic foundation of the learning competencies in the lower grade level to be familiar with the subject when they reach the higher grade levels (Perez et al., 2020). The SPA in teaching Mathematics is necessary (Tapanan et al., 2019) since some of the learning competencies were not attained in the last quarter of the curriculum guide due to factors affecting teachers' performance, comparable to ancillary functions (Into \& Gempes, 2018). Thus, project VLOGI was considered the solution for teachers who have extra duties aside from classroom teachers. Furthermore, when project VLOGI was used to promote SPA in mathematics education, learners could remove their mathematics anxiety while increasing their self-efficacy and self-esteem in dealing with complicated mathematical problems at a higher grade level.

Moreover, learners learn best when teachers vary their instructional delivery and employ as many interventions as possible to provide them with the opportunity to grasp the lesson in the most interactive and engaging multimedia instruction (Eren \& Ergulec, 2020), such as project VLOGI. These academic Vlogs for teaching were proven to be beneficial to learners in better understanding the subjects since they can see how the process/procedure should be done in full detail through Vlogs. Furthermore, using these Vlogs to illustrate the learning concepts, students may view and listen to the video as often as they like to promote intensive comprehension. Moreover, it was discovered that learners acquired information while creating Vlogs, and it fostered collaborative learning with their classmates as they engaged in accomplishing their project. In addition, learners may use vlogging to express ideas and show skills without the constraints of writing because not all students are excellent writers. These Vlogs could also enable them to utilize for a project that allows them to show what they know and the confidence to do so in the manner that they feel most comfortable. In addition, these Vlogs enable learners to study the learning content at their own pace, at any time, and in their environment. Likewise, learners may feel less pressured if they are allowed to ponder about a subject and listen to a lecture several times as they need without being pressured to move on by the rest of the class. Hence, learners may be more focused at various times of the day or in other environments compared to a classroom or school setting.

Furthermore, this project VLOGI was viewed as beneficial to teachers regarding their obligation as classroom teachers and their additional responsibilities at school. These Vlogs could help them maximize their time and efforts without affecting their performances in accomplishing their duties (Into \& Gempes, 2018). Moreover, project VLOGI was regarded as an alternate method in teaching when the teacher is away from the class discussion due to ancillary school functions. Consequently, since the teachers had never left the class alone because the project VLOGI was presented to them, it is possible to achieve all of the learning competencies of the curriculum guide before the school year ends. Similarly, the Vlogs produced by project VLOGI should be saved for future use or improved for long- 
term development in education. Hence, teachers may continuously enhance the limitations of their academic Vlogs, allowing them to discover the deficiencies of the instructional video when used frequently.

\subsection{The Performed Actions to Incorporate Project VLOGI into Mathematics Instruction}

These taken actions may include but are not limited to presenting the study's significant results to school administrators to garner stakeholder support for the broad adoption of the VLOGI project in any discipline for teaching (Abulencia, 2019). The same is valid for reporting to higher-level authorities, such as district supervisors and education program supervisors in Mathematics, to support teachers' ongoing professional development in accordance with the DepEd's commitment and the principle of life-long learning (DepEd Order 35, 2016). Consequently, the researcher may establish a school-based Learning Action Cell (LAC) and In-service Training (INSET) for public school teachers at the district or division level to demonstrate how this project VLOGI is beneficial to classroom teachers. Similarly, the researcher may show how to develop instructional Vlogs utilizing offline applications for long-term educational sustainability development. Finally, since this experimental study was used to take action on the identified problems with the teaching and learning mathematics eight subject of Probability and Statistics, the researcher has to embrace putting this intervention project VLOGI into action. Some teachers at higher grade levels and teaching in any discipline should use similar interventions such as educational Vlogs for instructions. Likewise, for learners to achieve the necessary learning skills before the closing of the school year, this project VLOGI may be used to promote the spiral progression approach (SPA) in teaching (Perez et al., 2020). SPA is beneficial to learners because it could help them understand the basic concepts in mathematics they had in earlier grades. Then, they will be acquainted with the learning concepts in the higher grade level, eliminating mathematics anxiety (Kunwar, 2020) and fostering self-efficacy among middle school learners (Sevgi \& Gurtas, 2020) in facing their math subject. This platform may assist teachers in managing their time and provide equal practice to learners who were still studying alone using this approach even without teacher supervision.

\section{Recommendation}

The project VLOGI is an instructional method that involves time and effort on the part of the teacher to prepare, record, and edit a high-quality video presentation to be delivered to learners through different teaching modalities. The most well-known method for learners, especially the digital natives, to access this intervention is via social networking sites such as YouTube, Facebook, and others (Erol et al., 2020; Fountain, 2017). However, learners may watch these academic Vlogs (project VLOGI) in their classes or through the school's audio-visual room, e-classroom, or even in their homes when needed. Teachers in any discipline may utilize this technique to fill in the gaps caused by ancillary functions such as meetings, seminars, reports, assessments, etc. Others may be in the context of an online forum where unforeseen catastrophes, calamities, and public health crises (pandemics) prevent students from attending classes.

Moreover, international and local readers, researchers, and teachers should consider this research topic regarding academic Vlogs for instructions and the study's limitations to incorporate them into future research. Vlogs may or may not be familiar to people in other countries, but the researcher believes that establishing a project VLOGI for learners may help students develop their 21st-century skills. They will improve not limited to media and technological literacy; but also in other skills such as critical thinking, creativity, teamwork, communication, adaptability, and social skills. Similarly, this method could be timely and relevant in this pandemic, where teachers could incorporate this project VLOGI into their instructions, even in asynchronous or synchronous learning platforms.

\section{Acknowledgment}

The author wishes to offer his heartfelt thanks to the Department of Education (DepEd) Basic Education Research Fund (BERF), Region VI - Western Visayas, Philippines, for awarding and financing this research. Similarly, the author wants to extend gratitude to Schools Division Office (SDO) - Aklan, the 
Office of the District Supervisor in Malay, Aklan, and the Office of the Principal of Malay National High School School, Motag, Malay, Aklan, Philippines, for granting his request to conduct his study as well as permitting to present and publish his research outside the country. Nothing would be possible without the participation of the research participants and their parents' permission to collaborate with the researcher throughout the study. A million thanks to all of you.

\section{References}

Abad, J. R., \& Arellano, A. D. (2020). Spiral progression approach in teaching junior high school mathematics. IOER International Multidisciplinary Research Journal, 2(4). 68-78. Retrieved from https://www.scribd.com/user/441795099/IOER-International-Multidisciplinary-ResearchJournal-IIMRJ

Abah, J. A. (2020). An Appeal in the Case involving Conventional Teaching: Emphasizing the Transformation to Enhanced Conventional Teaching in Mathematics Education. VillageMath Educational Review (VER), 1(1), 1-10. Retrieved from DOI: 10.5281/zenodo.3860320

Abulencia, A. (2019). Lived experience of principals in the implementation of $\mathrm{k}$ to 12 program in the philippines. EDUCARE: International Journal for Educational Studies, 12(1), 1-24. Retrieved from https://journals.mindamas.com/index.php/educare/article/view/1243

Aizikovitsh-Udi, E. (2019). Construction of critical thinking skills by the infusion approach in probability and statistics in daily life. Eleventh Congress of the European Society for Research in Mathematics Education, 1-9. Retrieved from https://hal.archives-ouvertes.fr/hal-02421215

Al-Maroof, R. S., Salloum, S. A., Hassanien, A. E., \& Shaalan, K. (2020). Fear from COVID-19 and technology adoption: the impact of google meet during the coronavirus pandemic. Interactives Learning Environments, 1(16). Retrieved from https://doi.org/10.1080/10494820.2020.1830121

Alegre, E. M., \& Hazel Mae, L. (2019). The level of impact on spiral progression approach in mathematics to the academic performance of the grade 10 students. International Journal of Scientific and Research Publication, 9(4), 504-512. Retrieved from http://dx.doi.org/10.29322/IJSRP.9.03.2019.p8863

Ariel, B., Bland, M., \& Sutherland, A. (2021). Experimental Designs. The SAGE Quantitative Research Kit. SAGE Publications Ltd. Retrieve from https://www.researchgate.net/publication/352038974

Batubara, K., \& Natali, C. H. (2020). Improving the speaking skill by vlog as learning media for teaching long functional text for eight grade students at SMPN 17 medan. Randwick International of Education and Linguistics Science (RISS) Journal. 1(3), 363-371. Retrieved from https://doi.org/10.47175/rielsj.v1i3.144

Behesti, M., Taspolat, O., Kaya, O. S., \& Sapanca, H. F. (2018). Characteristics of instructional videos. World Journal on Educational Technology: Current Issues. 10(1). 61-69. Retrieved from https://eric.ed.gov/?id=EJ1170366

Bravo, E., Amante, B., Simo, P., Enache, M, \& Fernadez, V. (2011). Video as a new teaching tool to increase student motivation. 2011 IEEE Global Education Conference (EDUCON), 638 - 642. Retrieved from https://doi.org/10.1109/EDUCON.2011.5773205

Buensuceso, D. B. (2015). Level of mastery of the competencies on fractions: basis for the proposed intervention program. The International Conference on Language, Humanities, E Innovation. 196204. Retrieved from https://www.academia.edu/40266383/Level_of_Mastery

Capate, R. N. A., \& Lapinid, M. R. C. (2015). Assessing the mathematics performance of grade 8 students as basis for enhancing instruction and aligning with $\mathrm{k}$ to 12 curriculum. Proceedings of the DLSU Research Congress 2015, 3, 3-7. Retrieved from https://animorepository.dlsu.edu.ph/etd_masteral/4738 
Chanoknath, S., \& Louangrath, P.I. (2015). Descriptive and inferential statistics. International Journal of Research \& Methodology in Social Science, 1(1), 22-35. Retrieved from http://doi.org/10.5281/zenodo.1320727

Chatterjee, K. \& Mukherjee, D. (2016). On the estimation of homogeneous population size from a complex dual-record system. Journal of Statistical Computation and Simulation, 86(17), 3562-3581. Retrieved from https://doi.org/10.1080/00949655.2016.1173695

da Silva, B. G., Borges, Y. M., \& Galo, R. (2020). The use of ludic resources for the teaching of probability and statistics in middle school. Research Society and Development, 9(11), 1-18. Retrieved from https://doi.org/10.33448/rsd-v9i11.10672

Dangle, Y. R. P., \& Sumaoang, J. D. (2020). The implementation of modular distance learning in the philippines secondary public schools. 3rd International Conference on Advanced Research in Teaching and Education. 100-108. Retrieved from https://www.dpublication.com/abstract-of-3rdicate/27-427/

Deken, C., Neuman, I., \& Heinze, A. (2020). Mathematical prerequisites for STEM programs: what do university instructors expect from new STEM undergraduates? International Journal of Research in Undergraduate Mathematics Education, 6, 23-41. Retrieved from http://dx.doi.org/10.1007/s40753-019-00098-1

Department of Education (1988). DO. 35, s. 1988. Utilization of instructional materials and accountability therefore. Retrieved from https://www.deped.gov.ph/1988/05/06/do-35-s-1988-utilization-ofinstructional-materials-and-accountability-therefor/

Department of Education (2005). DO. 9, s. 2005 - Instituting measures to increase engaged time-on-task and ensuring compliance therewithin. Retrieved from https://www.deped.gov.ph/2005/03/02/do-9-s2005-instituting-measures-to-increase-engaged-time-on-task-and-ensuring-compliancetherewith/

Department of Education (2009). DO. 109, s. 2009. Make-up classes for loss schooldays. Retrieved from https://www.deped.gov.ph/wp-content/uploads/2009/10/DO_s2009_109.pdf

Department of Education (2016). K to 12 Curriculum guide mathematics (grade 1 to grade 10). Retrieved from https://www.deped.gov.ph/wp-content/uploads/2019/01/Math-CG_with-tagged-mathequipment.pdf

Department of Education (2016). DO. 35, s. 2016. The learning action cell as a K to 12 basic education program school-based continuing professional development strategy for the improvement of teaching and learning. Retrieved from https://www.deped.gov.ph/wp-content/uploads/2016/06/DO_s2016_035.pdf

Eren, E. \& Ergulec, F. (2020). Teknolojik pedagojik içerik bilgisi tabanlı öğretim tasarımı modeli: okulüniversite işbirliği kapsamında bir değerlendirme. Kırşehir Eğitim Fakültesi Dergisi, 21(3), 12471290. Retrieved from DOI: $10.29299 /$ kefad. 853475

Ernawati, \& Sutiarso, S. (2019). Analysis of difficulties in solving mathematical problems categorized higher order thinking skills (HOTS) on the subject of rank and shape of the root according to polya stages, Journal of Physics: Conference Series, 1563, 1-8. Retrieved from DOI: 10.1088/17426596/1563/1/012041

Erol, O., Çırak, N. S. \& Beşer-Gülsoy, V. G. (2021). Sosyal medya kullanımının kişiliğe göre değişimi: öğretmen adayları örneklemi. Kırşehir Eğitim Fakültesi Dergisi, 22(1), 571-598. Retrieved from DOI:10.29299/kefad.766015

Fidan, M., \& Debbag M. (2018). The usage of video blog (vlog) in the "school experience" course: the opinion of the pre-service teachers. Journal of Education and Future, 13, 161-177. Retrieved from https://dergipark.org.tr/en/download/article-file/420174 
Fitriani, U., \& Rohman A. A. (2021). Students' Mathematical Communication Skills Through Vlog in Project-based Learning Based on the Unity of Science. Journal of Physics: Conference Series, 1796 (2021), 012119. Retrieved from doi:10.1088/1742-6596/1796/1/012119

Fountain, M. (2017). Social media and its effects in politics: the factors that influence social media use for political news and social media use influencing political participation [Undergraduate Research Thesis, The Ohio State University]. Retrieved from https://kb.osu.edu/bitstream/handle/1811/81616/Thesis_Megan_Fountain.pdf?sequence=1\&isA llowed=y

Fritz, C. O., Morris, P. E., \& Richler, J. J. (2012). Effect size estimates: current use, calculations, and interpretations. Journal of Experimental Psychology General, 14(1), 2-18. Retrieved from http://dx.doi.org/10.1037/a0024338

Gafoor, K. A., Kurukkan, A. (2015, August 18-19). Why High School Students Feel Mathematics Difficult? An Exploration of Affective Beliefs. [Paper Presentation]. UGC Sponsored National Seminar on Pedagogy of Teacher Education- Trends and Challenges. Farook Training College, Kozhikode, Kerala. Retrieved from https://eric.ed.gov/?q=Mathematics+as+Difficult+subject\&id=ED560266

Gao, W., Tian, Y., Huang, T., \& Yang, Q. (2010). Vlogging: a survey of videoblogging technology on the web. ACM Computing Survey, 42(4), 15:1 - 15:57. Retrieved from http://doi.acm.org/10.1145/1749603.1749606

Hae-Young, K. (2019). Statistical notes for clinical researchers: the independent samples t-test. Restorative Dentistry \& Endodontics (RDE), 44(3), 1-6. Retrieved from https://doi.org/10.5395/rde.2019.44.e26

Hernando-Malipot, M. (2019, June 25). Teachers' group laments lack of textbook for K to 12. Manila Bulletin, p 9. Retrieved from https://www.pressreader.com/philippines/manilabulletin/20190625/281792810561020

Huang, H. (2021). Effects of smartphone-based collaborative vlog projects on EFL learners' speaking performance and learning engagement. Australasian Journal of Educational Technology, 37(6), 1840. Retrieved from https://doi.org/10.14742/ajet.6623

Into, C. A. D., \& Gempes, G. P. (2018). Untold stories of teachers with multi ancillary functions: a phenomenology of fortitude. Journal of Advances in Humanities and Social Sciences, 4(18), 13-25. Retrieved from https://www.tafpublications.com/gip_content/paper/Jahss-4.1.2.pdf

Jaron, M. A. E., Sandoval, M. P., \& Garcia. F. A. (2015). As assessment of organizational commitment among selected administrative employees of Yazaki-Torres manufacturing, inc. CAS Research Journal, 2(2), 201-237. Retrieved from https://lpulaguna.edu.ph/wpcontent/uploads/2016/10/AN-ASSESSMENT-OF-ORGANIZATIONAL-COMMITMENTAMONG-SELECTED-ADMINISTRATIVE-EMPLOYEES-OF-YAZAKI-TORRESMANUFACTURING.pdf

Kaur, P., Stoltzfus, J., \& Yellapu, V. (2018). Descriptive analysis. IJAM - International Journal of Academic Medicine, 4(1), 60-63. Retrieved from http://www.ijam-web.org/text.asp?2018/4/1/60/230853

Khoule, A. , Bonsu, N. O. \& El Houari, H. (2017). Impact of Conceptual and Procedural Knowledge on Students' Mathematics Anxiety. International Journal of Educational Studies in Mathematics, 4 (1), 8-17. Retrieved from https://dergipark.org.tr/en/pub/ijesim/issue/34535/381574

Kilicaslan, H., \& Vural, S. (2018). The effects of creative drama teaching methods on academic success in architectural education. EURASIA Journal of Mathematics, Science and Technology Education, 14(6), 2157-2167. Retrieved from https://doi.org/10.29333/ejmste/86613 
Kırıkçılar, R. G. \& Yıldız, A. (2019). Developing an Observation Form to Determine the TPACK Usage. International Journal of Educational Studies in Mathematics, 6 (4), 172-181. Retrieved from https://dergipark.org.tr/en/pub/ijesim/issue/50978/628888

Kunasaraphan, K. (2018). Classroom action research for teaching mathematics in secondary schools. The ICBTS Research Conference Proceedings 2018 in Vienna, 433 -437. Retrieved from http://www.elic.ssru.ac.th/kanokrat_ku/mod/page/view.php?id=6

Kunwar, R. (2020). Mathematics phobia: causes, symptoms, and ways to overcome. International Journal of Creative Research Thoughts (IJCRT), 8(8), 818-822. Retrieved from http://www.ijcrt.org/papers/IJCRT2008103.pdf

Lalian, O. N. (2019). The effects of using video media in mathematics learning on students' cognitive and effective aspects. AIP Conference Proceedings 2019, 030011, 1-4. Retrieved from https://aip.scitation.org/doi/10.1063/1.5061864

Landau, S. \& Evirett, B. (2004). A handbook of statistical analyses using SPSS. Chapman \& Hall/CRC Press LLC. Retrieved from https://www.academia.dk/BiologiskAntropologi/Epidemiologi/PDF/SPSS_Statistical_Analyses _using_SPSS.pdf

Machera, R. P. (2017). Teaching intervention strategies that enhance learning in higher education. Universal Journal of Educational Research, 5(5), 733-743. Retrieved from DOI: 10.13189/ujer.2017.050505

Mayer, R. E. (2014). Cognitive theory of multimedia learning. In R. E. Mayer (Ed.), The Cambridge Handbook of Multimedia Learning (pp. 43-71). Cambridge University. Retrieved from https://doi.org/10.1017/CBO9781139547369.005

Mullis, I. V. S., Martin, M. O., Goh, S., \& Cotter, K. (Eds.). (2016). TIMSSS 2015 encyclopedia: education policy and curriculum in mathematics and science, TIMSS \& PRILS International Study Center website. http://timssandpirls.bc.edu/timss2015/encyclopedia/

Muniz-Rodriguez, L., Rodriguez-Muniz, L. J., \& Alsina, A. (2020). Deficits in the statistical and probabilistic literacy of citizens: effects in a world in crisis, mathematical modelling and simulation in science and engineering MDPI. E Mathematics, 8(11), 1-20. Retrieved from https://doi.org/10.3390/math8111872

Orale, R. L., \& Uy, M. E. A. (2018). When the spiral is broken: problem analysis in the implementation of spiral progression approach in teaching mathematics. Journal of Academic Research, 3(3), 1424. Retrieved from https://www.researchgate.net/publication/327232436

Overton, C. E., Stage, H. B., Ahmad, S., ..., Webb, L. (2020). Using statistics and mathematical modeling to understand infectious disease outbreaks: COVID-19 as an example. Infectious Disease Modelling, 5, 409-441. Retrieved from https://doi.org/10.1016/j.idm.2020.06.008

Paring, I. R., Cereno, A. C., \& Decano, R. (2021). Determining factors to students' science achievement in the implementation of $\mathrm{K}$ to 12 spiral progression approach: a mixed method. International Journal of Educational Research Review, 6(3), 46-54. Retrieved from https://ejournal.usd.ac.id/index.php/IJIET/article/view/2983

Paul, J. \& Jefferson, F. (2019). A comparative analysis of student performance in an online vs. Face-toface environmental science course from 2009 to 2016. Frontiers in Computer Science, 1(7), 1-9. Retrieved from https://doi.org/10.3389/fcomp.2019.00007

Perez, J. C. S., Bongcales, R. C. A., \& Bellen, J. A. (2020). A scoping on the implementation of the spiral progression approach. Journal of Academic Research, 1(1), 11-22. Retrieved from https://www.researchgate.net/publication/343304741 
Rakhmanina, L., \& Kusumaningrum, L. (2017). The effectiveness of video blogging in teaching speaking viewed from students' learning motivation. Proceedings of ISELT FBS Universitas Negeri Padang, 5, 27-34. Retrieved from http://ejournal.unp.ac.id/index.php/selt/article/viewFile/7980/6083

Rashid, M., \& Zaman, S. (2018). Effects of teacher's behavior on academic performance of students. $3^{\text {rd }}$ International Conference on Research and Practices in Education, 1-15. Retrieved from https://www.researchgate.net/publication/325248514

Read, L., \& Atinc, T. M. (2017). Investigation into using data to improve learning Philippine case study. Global Economy and Development. Brookings 1775 Massachusetts Avenue, NW Washington, DC. Retrieved from https://www.brookings.edu/wp-content/uploads/2017/03/global-20170307philippines-case-study.pdf

Ridhawaanah, H. D., \& Khemduth, S. A. (2019). Impact of spiral teaching on quadratics: action research with grade 11 students in mauritius. Proceedings of the $42^{\text {nd }}$ Annual Conference of the Mathematics Education Research Group of Australasia, 220-227. Retrieved from https://eric.ed.gov/?id=ED604303

Rigo, F, \& Mikus, J. (2021). Asynchronous and synchonous distance learning of english as a foreign language. Media Literacy and Academic Research, 4(1), 89-106. Retrieved from https://www.mlar.sk/wp-content/uploads/2021/04/6_Rigo_Mikus.pdf

Rosenbusch, K. (2020). Technology intervention: rethinking the role of education and faculty in the transformative digital environment. Advances in Human Developing Resources, 22(1), 87-101. Retrieved from https://doi.org/10.1177/1523422319886297

Rozgonjuk, D., Kraav, T., Mikkor, K., Orav-Puurand, K., \& That, K. (2020). Mathematics anxiety among STEM and social science students: the roles of mathematics self-efficacy, and deep and surface approach to learning. International Journal of STEM Education, 7(46), 1-11. Retrieved from https://doi.org/10.1186/s40594-020-00246-z

Shivaraju, P. T., Manu, G., Vinaya, M., \& Savkar M. K. (2017). Evaluating the effectiveness of pre-and post-test model of learning in a medical school. National Journal of Physiology, Pharmacy and Pharmacology, 7(9), 947-951. Retrieved from http://dx.doi.org/10.5455/njppp.2017.7.0412802052017

Sevgi, S., \& Gürtaş, K. (2020). Ortaokul öğrencilerinin geometriye yönelik tutum ve öz-yeterliliklerinin incelenmesi. Kırşehir Ĕ̆itim Fakültesi Dergisi, 21(1), 416-455. Retrieved from DOI:10.29299/kefad.2020.21.01.012

Sumuglu, U. (2021). A case study on teaching Turkish through distance education. International Journal of Psychology and Educational Studies, 8(1), 174-190. Retrieved from https://doi.org/10.17220/ijpes.2021.8.1.278

Tapanan, H. E., Antig, M. G., \& Tapanan, M. L. J. (2021). Assessment of teacher' performance and the spiral progression approach in mathematics. International Journal of Innovative Science and Research Technology, 6(1), 668-675. Retrieved from https:/ijisrt.com/assets/upload/files/IJISRT21JAN493.pdf

Tiro, A. S. (2020). Description of probability and randomized events literacy for statistics students at university negeri makassar. Journal of Physics: Conference Series, (WEAST 2020), 1899, 1-6. Retrieved by doi:10.1088/1742-6596/1899/1/012097

Tuma, F. (2021). The use of educational technology for interactive teaching in lectures. Annals of Medicine and Technology, 62, 231-235. Retrieved from https://doi.org/10.1016/j.amsu.2021.01.051

Ullah, O., \& Iqbal, M. (2020). Comparison of Impact of Traditional and Modern Teaching Methods on Students' Performance at Elementary School Level. Global Regional Review, V(I), 386-395. Retrieved from http://dx.doi.org/10.31703/grr.2020(V-I).42 
Yumusak, G. K. (2016). An analysis of the science curricula in turkey with respect to spiral curriculum approach. Journal of Education and Practice, 7(9), 99-105. Retrieved from http://files.eric.ed.gov/fulltext/EJ1095823.pdf

Zamalia, M., \& Porter, A. (2016). Students' perceived understanding and competency in probability concepts in an e-learning environment: an australian experience. Pertanika Journal Social Sciences $\mathcal{E}$ Humanities, 24, 73-82. Retrieved from http://ro.uow.edu.au/eispapers/6547 